\title{
Overview of Cerebral Palsy and Non-Surgical Treatment Methods
}

\author{
Serebral Palsi'ye Genel Bakışve Cerrahi Dışı Tedavi Yöntemleri \\ Ahmet Aybar, Atilla Sancar Parmaksızoğlu \\ Department of Orthopaedics and Traumatology, Taksim Training and Research Hospital, İstanbul, Turkey
}

\begin{abstract}
Cerebral Palsy (CP) is the most common of the childhood neuromuscular diseases and generally leads to permanent disability. Voluntary motor control impairment is the basic clinical manifestation. While the superficial sensation is generally normal, the cortical perception, joint position sense (proprioception) and the sensation of movement (kinesthetic perception) are impaired. The peripheral reflections (contractures, bone deformities) of the cerebral lesion are progressive. Cerebral injury resulting in cerebral palsy may develop in prenatal, perinatal or postnatal periods. However prenatal factors are mostly involved. The most significant risk factors include prematurity and low birth weight. Classification is made based on the tonus changes, the type of movement disorder and the number of extremities affected, rather than the cerebral lesion. Clinical and anatomic classification is used commonly. CP treatment aims to assist in increasing the physical, cognitive and communication capacity, achieving and maintaining mental balance for the individual and the family. It is multidisciplinary. (JAREM 2012; 2: 38-42)
\end{abstract}

Key Words: Cerebral palsy, classification, non-surgical treatment methods

\section{ÖZET}

Serebral Palsi (SP) çocukluk çağı nöromüsküler hastalıklarının en yaygını olup, genellikle kalıcı özürlülüğe neden olur. Klinik tablodaki en temel sorun istemli motor kontrol bozukluğudur. Yüzeyel duyu genellikle normal olmakla birlikte kortikal algılama, eklem pozisyon hissi (propriyosepsiyon) ve hareket hissi (kinestetik algılama) bozuktur. Beyindeki lezyonun periferik yansımaları (kontraktürler, kemik deformiteleri) ilerleyicidir. Serebral Palsi'ye yol açan beyin hasarı, prenatal, perinatal veya postnatal dönemlerde gelişebilir. En önemli risk faktörleri prematürite ve düşük doğum ağırlığıdır. Sınıflama beyindeki lezyonun yerine, tonus değişikliklerine, hareket bozukluğunun tipine ve etkilenen ekstremite sayısına göre yapılır. Yaygın olarak klinik ve anatomik sınıflandırma kullanılır. SP tedavisinde fiziksel, bilişsel fonksiyonların ve iletişimsel kapasitesinin artırılması, bireyin ve ailesinin ruhsal dengelerini kurması ve korumasına yardım edilebilmek amaçlanır. Multi disiplinerdir. (JAREM 2012; 2: 38-42)

Anahtar Sözcükler: Serebral palsi, sınıflandırma, cerrahi dışı tedavi

\section{INTRODUCTION}

Cerebral Palsy (CP) is the most common of the childhood neuromuscular diseases and generally leads to permanent disability.

Although it has been over a century since the disease was initially described, the cause still remains unclear (1). Voluntary motor control impairment is the basic clinical manifestation. The voluntary movements cannot be fully controlled and balance cannot be achieved due to impaired trunk balance reactions, and changes in the muscle tone such as spasticity and dystonia. While the superficial sensation is generally normal, the cortical perception, joint position sense (proprioception) and the sensation of movement (kinesthetic perception) are impaired. The peripheral reflections (contractures, bone deformities) of the cerebral lesion are progressive (2).

The SP prevalence is 0.6-7 per 1000 live births (3). Epidemiological studies in several countries reveal a rate of 1.51-2.2/1000 for Europe, 1.7-2.0/1000 for USA and 1.28-1.92/1000 for China (4-9). While there are no reliable, adequate statistics on this subject in our country, the rate of $\mathrm{CP}$ is reported to be $2-8 / 1000$ in the whole population $(2,10)$. There is no marked improvement in the prevalence or the treatment despite the developing prophylactic healthcare services; however the advances in perinatal care result in a larger number of children under risk for $\mathrm{CP}(11,12)$. Cerebral injury resulting in cerebral palsy may develop in prenatal, perinatal or postnatal periods. However prenatal factors are mostly involved. The most significant risk factors include prematurity and low birth weight (Table 1) (13).

\section{CLASSIFICATION}

Classification is made based on the tonus changes, the type of movement disorder and the number of extremities affected, rather than the cerebral lesion. Clinical and anatomic classification (Table 2) is commonly used (3). However, since CP may manifest with very different clinical findings, it may not be possible to categorize every child into a specific CP table.

\section{Physiologic Classification}

This is the classification made based on the distribution or findings of the motor impairment in the body.

Spasticity among the cortex lesions, athetosis/dystonia among the basal ganglion lesions, and ataxia/hypotonia among the cerebellar lesions dominates.

1. Spastic Type (pyramidal): $80 \%$ of the quadriparetic, hemiparetic, diparetic, monoparetic, and triparetic SPs are of the spastic type. To evaluate the spasticity, the joint is moved passively at a 
Table 1. Risk factors (13)

\section{Risk factors}

Prenatal

- Infections (TORCH (toxoplasmosis, rubella, cytomegalovirus, herpes simplex)

- Blood incompatibility (injury to several cerebral sites due to Rh group incompatibility can be avoided by treatment of Rh negative mothers)

- Placental causes (placental abnormalities, placental failures, placental infections)

- Alcohol and drug use by the mother

- Trauma

- Radiation

\section{Birth}

- Prematurity (birth earlier than 36 weeks)

- Low birth weight (<2500 grams)

- History of a difficult/medically intervened birth

- (Hypoxic ischemic encephalopathy)

- Neonatal attack (arterial, cynoveous)

- Traumatic cerebral injury

- Intracranial bleeding

\section{Presentation abnormalities}

- Small pelvic structure of the mother

- Multiple pregnancy

Postanatal (0-6 age)

- Neonatal hyperbilirubinemia

- Neonatal infections

- Sepsis

- Meningitis

- Central nervous system infections

- Convulsions

- Head trauma

constant speed and the resistance felt may be assessed using the Ashworth Scale (Table 3) (2).

2. Dyskinetic Type (extrapyramidal): Athetosis, chorea, dystonia, hypotonic. $10-15 \%$ of the CPs is of the dyskinetic type.

It results from injury to the centers in the thalamus and cerebellar region that are responsible for the coordinated movements, balance and fine motor movements. Athetosis represents involuntary wormlike squirming movements. The opposite muscles contract together (agonist and antagonist muscles). As the child attempts to make a move for a particular purpose, this squirming movement is further increased. It mostly involves the face, tongue, arms and the distal parts of the legs. Dyskinetic type involves involuntary moves that exhibit tonus changes over time. The patients are hypotonic at the start and develop athetosis, dystonia or chorea over time. Dystonia involves an increased tonus, however this is not dependent on the speed of the muscle movement as is the case in spasticity. It is not possible to reduce
Table 2. Anatomic classification

\section{Anatomic classification:}

Monoplegia

One extremity involved, usually lower

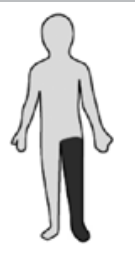

\section{Hemiplegia}

Both extremities on same side involved

Usually upper extremity involved more than lower extremity

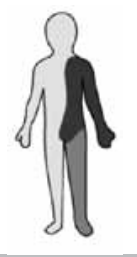

\section{Paraplegia}

Both lower extremities equally involved

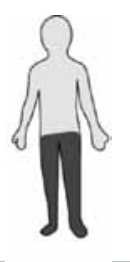

\section{Diplegia}

Lower extremities more involved than upper extremities

Fine-motor/sensory abnormalities in upper extremity

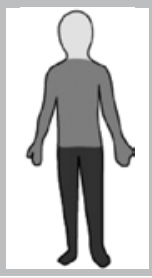

\section{Quadriplegia}

All extremities involved equally

Normal head/neck control

\section{Double hemiplegia}

All extremities involved, upper more than lower

\section{Total body}

All extremities severely involved

No head/neck control

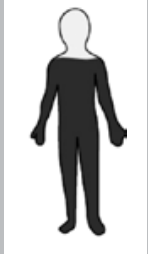

Adapted from Canale\&Beaty: Campbell's Operative Orthopaedics, $11^{\text {th }}$ ed. Mosby, Elsevier 2007

the tonus and rigidity is defined. Postural impairment dominates and commonly involves the proximal parts of the arms and legs and the trunk. Chorea is the involuntary, sudden, little movements. Generally, it develops in the feet and legs. In hypotonic 
Table 3. Ashworth scale (2)

a. No increased resistance against the joint movement, natu-
ral tonus
b. Mildly increased resistance against the joint movement
c. Markedly increased resistance against the joint movement,
movement is completed with difficulty.
d. The extremity is rigid, it cannot be moved.

children, the reduced muscle tonus turns into spasticity as age increases.

3. Ataxic Type/Atonic Type (cerebellar): It is a rare manifestation and may be briefly described as balance disorder. The children walk clumsily by opening their feet to achieve balance.

4. Mixed type (10-15\%): No one system is optimal for the classification and description of patients with cerebral palsy because of their heterogeneity. Because many patients exhibit variable patterns of motor activity that do not fit completely into one category or another, an individualized approach should be used for each patient. Palisano et al. developed the Gross Motor Function Classification System to help resolve these classification difficulties (Table 4) (3). This five-level numeric grading system, which has been found to be a reliable and stable method of classification and prediction of motor function for children 2 to 12 years old, takes into account functional limitations for assistive devices, such as walkers and wheelchairs, and the quality of movement based on age. The emphasis of this scale is on self-initiated movement and walking and sitting functions. Soo et al. reviewed a 3-year cohort of 323 children born with cerebral palsy in Australia and classified them according to this scale. They found that $35 \%$ had grade I function; $16.4 \%$, grade II; $14.2 \%$, grade III; $16.1 \%$, grade IV; and 18\%, grade V. Most patients with hemiplegia had grade I or II function, whereas patients with either diplegia or quadriplegia were distributed across all grades (3). Canale et al. (3) also found that the Gross Motor Function Classification System grade was predictive of hip dislocation (3).

\section{The other disorders accompanying cerebral palsy}

While the fundamental disorder is motor retardation in cerebral palsy, the cerebral injury is not limited to the motor site. Other nervous system-related disorders may also occur in addition to the movement system. These include epilepsy (in 1/3-1/2), mental retardation (65\%), oral-motor deficiency, malnutrition, visual and visuomotor impairment (50-80\%), reduced hearing, chronic lung diseases, motor speech disorders, behavioral disorders, sleep disorders, orthopedic disorders and urinary system disorders. Detection and treatment of these disorders affects the development of the children with CP positively $(14,15)$.

\section{Non-surgical CP treatment}

$\mathrm{CP}$ treatment aims to assist in increasing the physical, cognitive and communication capacity, achieving and maintaining mental balance for the individual and the family. It is multidisciplinary (pediatrist, pediatric neurologist, orthopedist, pediatric surgeon, pediatric psychiatrist, brain surgeon, otorhinolaryngologist, physiotherapist, work-occupation therapist, hearing-speaking therapist, audiologist, psychologist, pediatric development expert, private training expert). The primary requirement of the

\section{Table 4. Gross motor function classification system}

\section{GMFCS levell}

Children walk indoors and outdoors and climb stairs without limitation. Children perform gross motor skills including running and jumping. but speed. balance and co-ordination are impaired.

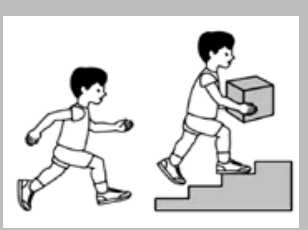

\section{GMFCS level II}

Children walk indoors and outdoors and climb stairs holding onto a railing but experience limitations walking on uneven surfaces and inclines and walking in crowds or confined spaces.

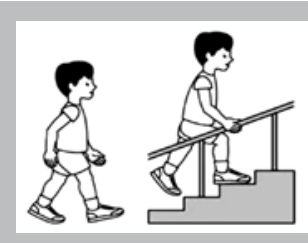

\section{GMFCS level III}

Children walk indoors on outdoors on a level surface with an assistive mobility device. Children may climb stairs holding onto railing. Children may propel a wheelchair manually or are transported when traveling for long distances or outdoors on uneven terrain.

\section{GMFCS leve IV}

Children may continue to walk for short distances on a walker or rely more on wheeled mobilily al home and school and in the community.

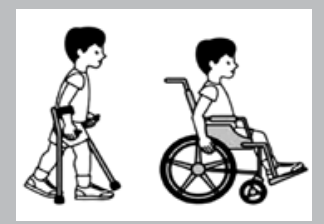

\section{GMFCS level V}

Physical impairment restricts voluntary control of movement and the ability to maintain antigravity head and trunk postures. All areased of motor function are limiled. Children have no means of independenl mobility and are transported.

www5.aaos.org/aaosscore/display.cfm?chapter $=\operatorname{ch} 30$

patient is communication. In children with speech disorder, one should try providing communication with the environment using special devices through verbal or non-verbal methods. If the family has adopted an over-protective attitude, the capacity of selfcare cannot develop. The secondary requirement is achievement of the independent movement capacity. Movement is necessary in order to be independent, participate in the social life and if possible, work in adulthood. Expectations from the child should be explained to the family and unrealizable targets should not be presented. Conservative treatment methods such as orthesis, medication and exercise should be shaped according to the course of the disease (2).

1. Oral medications: Pharmacological agents used for this purpose:

- Baclofen: Baclofen is the agonist of the gamma aminobutyric acid (GABA), the main inhibitor neurotransmitter in the central nervous system and can be used above 2 years of age. Baclofen mainly exerts its efficacy in the spinal cord; it increases the inhibitory effect of the interneuron on the second motor 
neuron and reduces spasticity. Intra-tracheal administration of baclofen enables a shorter time to achieve the effective dose in the receptors with lesser side effects $(2,16)$.

- Benzodiazepine derivatives (Diazepam, Clonazepam): Clonazepam has a similar efficacy as diazepam and has a longer duration of effect. It is preferred in children due to its lower sedative effect and the fact that it does not lead to respiratory distress.

- Dantrolen inhibits contraction by blocking the calcium release in the myofibril.

- Tizanidine is an alpha-2 adrenergic receptor antagonist. It is effective both on the brain and the spinal cord.

2. Neuromuscular blocks: In cases where medical treatment fails and surgery is considered to be risky, it is possible to create permanent lesions at several levels on the motor pathways using certain chemical agents.

Alcohol is used in the form of $10 \%$ ethyl alcohol.

Phenol is a carbolic acid; $3 \%$ preparation is used.

Botulinum A toxin: It is an exotoxin produced by Clostridium Botulinum. It creates chemical denervation by inhibiting the acetylcholine release in the neuromuscular junction. The effect has an onset on the $3^{\text {rd }}$ day, reaches maximum on the $10^{\text {th }}$ day and is maintained for 3 to 6 months with muscle relaxation. $6 \mathrm{iu} / \mathrm{kg}$ of toxin administration is recommended, however total administration should not exceed 12 iu per kg body weight. The disadvantages include a reversible effect and development of resistance (2).

\section{Physical therapy}

- Conventional exercise programs including stretching and strengthening exercises: Physical therapy is an essential component in the treatment of patients with cerebral palsy. Physical therapy typically is used as a primary treatment modality The therapist plays a crucial role in all aspects of care, including identifying children who may have cerebral palsy, treating their spasticity and contractures, fabricating splints and simple braces, providing family education and followup, acting as a liaison with the school and other health care providers, and implementing home stretching and exercise programs with the patients and their families. Because of the variability in patients with cerebral palsy, an individualized approach to therapy is necessary. Goals for ambulatory patients include strengthening of weakened muscles, contracture prevention, and gait and balance training; for severely affected individuals, goals are improvements in sitting balance, hygiene, and ease of care for caregivers. The parents should be encouraged from the beginning to take an active role in the child's therapy program (3).

- Neurofacilitation methods (Bobath, Vojta vb.) (2)

- Stimulation by electric current and repetitive magnetic field.

Electro-stimulation Methods: stimulation using low-frequency electric currents with the help of superficial electrodes placed on the spastic muscles was observed to reduce spasticity for short durations (2).
4. Orthesis and Corrective Plastering: Bracing, as with physical therapy and medication, is typically used in conjunction with other modalities. Bracing in patients with cerebral palsy is most commonly used to prevent or slow progression of deformity. The most commonly used braces for the treatment of cerebral palsy include ankle-foot orthoses, hip abduction braces, hand and wrist splints, and spinal braces or jackets. A patient-centered approach should be used. The goals of bracing for an ambulatory child differ from the goals for a child with severe involvement. Bracing of the lower extremities, most commonly with ankle-foot orthoses, is common in patients with cerebral palsy. These have been shown to improve gait function and decrease crouch during walking, even in the absence of surgery in ambulatory children. The goals of bracing in a severely affected child include facilitating shoe wear, preventing further progression of contractures, improving wheelchair positioning, and assisting standing programs. The use of floor-reaction ankle-foot orthoses, which use a plantar flexion-knee extension couple to help eliminate crouched-knee gait and improve stance phase knee extension, has dramatically decreased the need for bracing above the knee with knee-ankle-foot orthoses (3).

- Supramalleolar orthoses (SMOs) may be used to control coronal plane deformities of the foot and ankle (pronation or supination) but do not address the sagittal plane(equinus or calcaneus) (16).

- Ankle-foot orthoses (AFOs) may be used to stabilize the ankle joint.

i. Solid-ankle AFOs may be used to prevent equinus or a crouched stance due to uncontrolled dorsiflexion at the ankle. Prevention of equinus and calcaneus has been shown to improve walking speed and stride length for most children (16).

ii. Hinged AFOs may be used to allow dorsiflexion while preventing equinus during gait.

iii. Floor-reaction AFOs cause knee extension to improve crouched gait secondary to ankle plantar flexion weakness (16).

- Knee-ankle-foot orthoses (KAFOs) stabilize the knee and are useful for maintaining knee position in children who walk very limited distances or only stand (16).

5. Work-Occupation Treatment: This therapy is designed to enable children develop their motor movement planning skills, thereby achieving independence of cerebral palsy at school or at work (2).

6. Speech therapy: is often requisite, particularly in children with significant bulbar involvement (16).

Conflict of interest: No conflict of interest was declared by the authors.

\section{REFERENCES}

1. Bialik GM, Givon U. Cerebral palsy: classification and etiology. Acta Orthop Traumatol Turc 2009; 43: 77-80.[CrossRef]

2. Yalçın S, Özaras N. Dormans J. Serebaral Palsi Tedavi ve Rehabilitasyon; Mas Matbaacilık; 2000; 13-31, 51-6.

3. Canale \& Beaty: Campbell's Operative Orthopaedics, 11th ed Mosby, Elsevier 2007;1333-46. 
4. Pharoah POD, Cooke T, Johnson MA. Epidemiology of Cerebral Palsy in England and Scotland, 1984-1989; Arch Dis Child 1998; 79: 21-5.

5. Nordmark E, Hägglund G, Lagergren J. Cerebral Palsy in Southern Sweeden I. Prevelance and Clinical Features; Acta Pediatr 2001; 90; 1271-6.[CrossRef]

6. Wichers MJ, van der Schouw YT, Moons KG, Stam HJ, van Nieuwenhuizen O. Prevelance of Cerebral Palsy in The Netherlands (1977-1988). Eur J Epidemiol 2001; 17: 527-32.[CrossRef]

7. Winter S, Autry A, Boyle C, Yeargin-Allsopp M. Trends in the prevalance of Cerebral Palsy in a population-based study. Pediatrics 2002; 110: 1220-5.

8. Liang Y, Guo X, Yang G. Prevalence of cerebral palsy in children aged 1-6 in Guangxi, China; Zhonghua Yu Fang Yi Xue Za Zhi 2002; 36: 164-6.

9. Li S, Lin Q, Liu J. Prevalence of chilhood cerebral palsy in six provinces in China; Zhonghua Yi Xue Za Zhi 2001; 81: 1220-3.
10. Yöneyman F, Gürvit G, Yusuf M. Ro-CODEC Çocuklarda Kronik Hastalıkların Sıklığı Tarama Çalışması. MedicoGrafics ${ }^{\circ}, 1997 ; 83-4$.

11. Serdaroğlu A, Cansu A, Özkan S, Tezcan S. Prevalence of Cerebral Palsy inTurkish Children Between The Ages of 2 and 16 Years. Dev Med Child Neurol 2006; 48: 413-6.[CrossRef]

12. Reddihough DS, Collins KJ. The epidemiology and causes of cerebral palsy. Australian Journal of Physiotherapy 2003; 49: 7-12.

13. Grether JK, Nelson KB, Cummins SK. Twinning and cerebral palsy: experience in four Northern California counties, births 1983 through 1985. Pediatrics 1993; 92: 854-8.

14. Murphy CC, Yeargin-Allsoap M, Decoufle P, Drews CD. Prevalence of cerebral palsy among ten-year-old children in metropolitan Atlanta, 1989 through 1987. J Pediatr 1993; 123: 13-20.[CrossRef]

15. Lipkin PH. Epidemiology of the developmental disabilities. Caupte AJ, Accardo PJ, Eds. In: Developmental Disabilities in Infancy and Childhood, Baltimore: Brookes Co, 1993; 43-55.

16. $w w w 5$.aaos.org/aaosscore/display.cfm?chapter $=\mathrm{ch} 30$ 